\title{
Retrorectal Tumours: Literature ReVieW And Vilnius University Hospital “SANTARiskiu Klinikos” ExPERIENCE of 14 CASES
}

\author{
K. Strupas, E. Poskus, M. Ambrazevicius \\ Vilnius University Hospital „Santariskiu klinikos“ Centre of Abdominal Surgery, Vilnius University Medical Faculty, Lithuania
}

\begin{abstract}
Objective: Retrorectal tumours are rare lesions in adults. The diagnosis of retrorectal lesion is often difficult and misdiagnosis is common. We present significant number of cases in view of scarce information available on this matter.

Methods:14 patients were treated at Vilnius university hospital "Santariskiu klinikos" Centre of abdominal surgery from 1997 to 2010. The case notes of patients who underwent surgery for a retrorectal tumour were reviewed retrospectively. Surgical histories, operations, histological tumour type, surgical time, weight of the specimen, blood loss, length of stay were analysed.

Results: 13 patients underwent laparotomy, 1 patient had combined perineal approach and laparotomy. The most common types of the tumour were fibroma ( 3 cases), leiomyosarcoma ( 2 cases). 5 tumours $(35,7 \%)$ were found to be malignant. $57 \%$ of the patients had undergone at least one operation prior to definitive treatment. 5 female patients were initially admitted under gynaecologists. Hospital stay varied from 14 days to 22 days (mean 16,2 days). A report of a representative case is presented.

Conclusions: Retrorectal lesions in female patients can mimic gynaecological pathology. Patients with this rare pathology are to be treated in a major tertiary hospital by surgeons, who are able to operate safely in the retrorectal space.
\end{abstract}

Key words: retrorectal tumour, presacral mass, surgical management

\section{INTRODUCTION}

Retrorectal tumours (presacral, precoccygeal tumours) are rare lesions with late manifestations. The incidence of retrorectal tumours can be estimated to be 2,1 - 6,3 cases a year[1, 2]. The true incidence is masked by a fact that most of the studies were conducted in the tertiary referral centres and reported incidence may be much higher than in general population [3]. Spencer and Jackman [4] found precoccygeal cysts in 3 of 20,851 proctologic examinations $(0.014 \%)$ performed in a single year.

Retrorectal space, also referred as presacral space, is bounded by presacral fascia posteriorly, fascia propria of the rectum anteriorly and iliac vessels, ureters being found laterally. The peritoneal reflection of the rectum forms the roof of presacral space. Anatomically the space is divided by rectosacral fascia to inferior and superior portions. The floor of retrorectal space is formed by the fusion of the presacral parietal fascia and the rectal visceral fascia and lies above the levator ani muscle at the level of the anorectal junction [5].

Heterogeneous embryologic structures develop and involute adjacent to the retrorectal space, consequently leaving this area a potential site for a variety of both benign and malignant lesions.

Retrorectal tumours are classified to congenital, neurogenic, inflammatory, osseus and miscellaneous (Table 1). Congenital lesions are the most prevalent type, accounting for 55-65\% (some authors report

Table 1. Retrorectal tumours.

\begin{tabular}{lcl}
\hline Congenital (55-65\%): & Osseous $(5-11 \%):$ & Miscellaneous (12-16\%): \\
Developmental cyst (up to $60 \%$ of & Osteoma & Metastatic carcinoma \\
congenital lesions): & Osteogenic sarcoma & Lipoma/liposarcoma \\
Dermoid & Ewing's tumor & Fibrosarcoma \\
Epidermoid & Chondromyxosarcoma & Leiomyoma/leiomyosarcoma \\
Tailgut cyst & Giant cell tumor & Hemangioma \\
Teratoma & Inflammatory $(5 \%):$ & Carcinoid tumors \\
Teratocarcinoma & Perineal or pelvirectal abscess & Hemangioendothelial sarcoma \\
Chordoma & Diverticulitis & Extra-abdominal desmoid \\
Anterior sacral meningocele & Crohn's disease & Plasma cell myeloma \\
Rectal duplication & Foreign body granuloma & Endothelioma \\
Adrenal rest tumor & Infectious granulomas & Pelvic ectopic kidney \\
Neurogenic (10-12\%): & & \\
Neurofibroma & & \\
Ependymoma & & \\
Neurilemoma (Schwannoma) & & \\
Ganglioneuroma & & Compiled from references 1,2, 6, 8 \\
\hline
\end{tabular}


it being up to $80 \%$, including cysts and chordomas). Neurogenic tumours constitute $10-12 \%$, inflammatory $5 \%$, osseus $5-11 \%$, miscellaneous $12-16 \%$ [1, $2]$.

\section{Congenital Tumours}

The most common congenital retrorectal lesions are developmental cysts. They are more often diagnosed in females (male : female ratio 1:2) [2]. These tumours arise from abnormal closure of the ectodermal tube (dermoid and epidermoid cysts) and are lined with squamous epithelium with (dermoid) or without (epidermoid) skin appendages [9]. Tailgut cysts (cystic hamartomas) are less common: they are derived from tailgut remnants, the precursor of the gastrointestinal system. Malignant degeneration of tailgut cysts, associated with raised carcinoembryonic antigen level, is reported in literature [10].

The clinical presentation of developmental cysts is often non specific: most of them are asymptomatic, only infected and malignant cysts usually cause sacroccocygeal pain $[2,6]$. Late manifestations of retrorectal lesions can present as chronic constipation [11], pelvic outlet obstruction during labor [12]. Clinical signs may mimick those of pilonidal sinus [13], perianal abscess, fistula in ano. Singer et al. [14] report that patients had undergone a mean of 4,7 operations or invasive procedures to diagnose and treat their disease.

Clinical examination, revealing midline postanal dimples, immediately below the dentate line, suggest the presence of developmental cyst. They have been documented in 35 to 100 percent of patients [1, 14, 15]. Digital rectal examination can prove diagnosis in more than $90 \%$ of the cases $[2,7,15]$.

Chordoma is the most common malignant retrorectal mass, arising from remnants of the notochord [16]. Chordomas are slow-growing, locally invasive tumors that can reach large size before causing symptoms, such as low-back or sciatic pain, constipation, or lower-extremity paresis. Imaging will show a lytic lesion with a large soft-tissue mass [17].

Anterior sacral meningocele is a spinal fluid-filled sac in the pelvis communicating by a small neck with the spinal subarachnoid space through a defect in the sacrum. Headaches associated with defecation, recurrent meningitis or symptoms relating to mass effect indicate presence of anterior sacral meningocele [2]. Association with an anorectal malformation and sacral bony defect (Currarino syndrome) is reported in literature [19].

\section{Neurogenic and Osseus Tumours}

Osseous and neurogenic tumours make 20 to $30 \%$ of primary retrorectal tumours [6]. Due to compression or invasion of nearby neurological structures, the location of pain often follows radicular distribution [20]. Biological behaviour of osseus tumours is similar to bony tumours in other anatomic locations, with sarcomas having a predisposition for hematogenous spread to the lungs. All osseous masses have to be completely excised because of the high rate of recurrence [3].
Neurogenic lesions arise from nerve plexuses adjacent to retrorectal space. Lower back pain is typical clinical presentation, as well as other pelvic mass effect symptoms $[21,22]$.

\section{INFLAMMATORY AND MISCELLANEOUS LESIONS}

Inflammatory lesions arise from infection source below (perineal abscesses spreading superiorly to the supralevator space) or above (pelvic abscesses caused by diverticulitis, Crohn's or other intra-abdominal infection). They are not mentioned in several larger series, which makes their overall prevalence difficult to assess.

Miscellaneous lesions include tumours found elsewhere in the retroperitoneum, including metastatic disease (most commonly from the rectum), sarcomas, carcinoid tumors.

\section{Materials AND Methods}

Fourteen patients were treated at Vilnius university hospital "Santariskiu klinikos" Centre of abdominal surgery from 1997 to 2010. The case notes of patients who underwent surgery for a retrorectal tumour were reviewed retrospectively. The patients were comprised of 11 females and 3 males, with an age range of 37-79 years (mean, 55 years). Computed tomography (CT) was used to determine the infiltration of the tumour, the relation to other pelvic structures and possible malignant spreading. Magnetic resonance imaging (MRI) was used in addition to CT in 8 cases. Based on CT and MRI findings surgical plan was made for tumour removal. Tumours extending above S3 were extirpated using abdominal approach, whereas extension below S3 required perineal or combined approach. Biopsy was taken in 4 cases. Cases 1,2,6 had a course of radiotherapy. Case 1 had metastases in liver. Surgical histories, operations, histological tumour type, surgical time, weight of the specimen, blood loss, length of stay of 14 patients were analysed.

\section{RESULTS}

A list of the patients is shown in Table 2.13 patients underwent laparotomy, 1 patient had combined perineal approach and laparotomy. One patient underwent palliative operation. Three patients had rectum resection; colostomy was formed for 2 patients. The most common types of the tumour were fibroma ( 3 cases), leiomyosarcoma ( 2 cases). 5 tumours $(35,7 \%)$ were found to be malignant. Tumour weight was from $200 \mathrm{~g}$ to $853 \mathrm{~g}$ (mean $455 \mathrm{~g}$ ). Blood loss was from 50 $\mathrm{ml}$ to $4000 \mathrm{ml}$ (mean $821 \mathrm{ml}$ ). Time required for the surgery ranged from 1,3 hours to 5 hours (mean 3 hours). Hospital stay varied from 14 days to 22 days (mean 16,2 days). 57\% of the patients had undergone at least one operation prior to definitive treatment. 5 female patients were initially admitted under gynaecologists. There was no perioperative mortality. Case 10 was complicated by iatrogenic injury to left iliac vein, which was repaired during operation. There were two cases $(14 \%)$ with post operative wound infections. 
Table 2. Clinical data of the patients.

\begin{tabular}{|c|c|c|c|c|c|c|c|c|c|}
\hline No & $\begin{array}{l}\text { Age } \\
\text { (yrs) }\end{array}$ & $\begin{array}{l}\text { Gen- } \\
\text { der }\end{array}$ & $\begin{array}{l}\text { Surgical } \\
\text { procedure }\end{array}$ & $\begin{array}{l}\text { Histological } \\
\text { type }\end{array}$ & $\begin{array}{l}\text { Surgical } \\
\text { time } \\
(\mathrm{hrs})\end{array}$ & $\begin{array}{l}\text { Weight of } \\
\text { the } \\
\text { specimen (g) }\end{array}$ & $\begin{array}{l}\text { Blood } \\
\text { loss } \\
(\mathrm{ml})\end{array}$ & $\begin{array}{l}\text { Length } \\
\text { of stay } \\
\text { (days) }\end{array}$ & $\begin{array}{l}\text { No of } \\
\text { previous } \\
\text { operations }\end{array}$ \\
\hline 1 & 50 & $\mathrm{~F}$ & $\begin{array}{l}\text { Laparotomy } \\
\text { Extirpation }\end{array}$ & $\begin{array}{l}\text { Myxoid } \\
\text { embryonic } \\
\text { liposarcoma }\end{array}$ & 2,5 & 300 & 400 & 18 & 1 \\
\hline 2 & 57 & $\mathrm{~F}$ & $\begin{array}{l}\text { Laparotomy } \\
\text { Pallative excision }\end{array}$ & $\begin{array}{l}\text { Rhabdo- } \\
\text { myosarcoma }\end{array}$ & 2,25 & 200 & 600 & 19 & 1 \\
\hline 3 & 79 & M & $\begin{array}{l}\text { Laparotomy } \\
\text { Extirpation }\end{array}$ & $\begin{array}{l}\text { Malignant } \\
\text { haemangioma }\end{array}$ & 2,5 & 250 & 1500 & 14 & 0 \\
\hline 4 & 48 & $\mathrm{~F}$ & $\begin{array}{l}\text { Laparotomy and } \\
\text { perineal } \\
\text { extirpation }\end{array}$ & Fibroma & 3 & 700 & 500 & 13 & 0 \\
\hline 5 & 54 & M & $\begin{array}{l}\text { Laparotomy } \\
\text { Extirpation }\end{array}$ & Fibroma & 2,75 & 615 & 800 & 17 & 1 \\
\hline 6 & 68 & $\mathrm{~F}$ & $\begin{array}{l}\text { Extirpation with } \\
\text { rectum and } \\
\text { bladder resection }\end{array}$ & $\begin{array}{l}\text { Leiomyo- } \\
\text { sarcoma }\end{array}$ & 5 & 340 & 700 & 20 & 1 \\
\hline 7 & 69 & $\mathrm{~F}$ & $\begin{array}{l}\text { Extirpation with } \\
\text { rectum resection } \\
\text { and colostomy } \\
\text { formation }\end{array}$ & $\begin{array}{l}\text { Leiomyo- } \\
\text { sarcoma }\end{array}$ & 4 & 230 & 600 & 21 & 1 \\
\hline 8 & 39 & $\mathrm{~F}$ & $\begin{array}{l}\text { Laparotomy } \\
\text { Extirpation with } \\
\text { levator muscle } \\
\text { suturing }\end{array}$ & Lipoma & 2 & 680 & 800 & 10 & 0 \\
\hline 9 & 61 & M & $\begin{array}{l}\text { Extirpation and } \\
\text { formation of the } \\
\text { colostomy }\end{array}$ & $\begin{array}{l}\text { Immature } \\
\text { teratoma }\end{array}$ & 3,25 & 280 & 400 & 17 & 1 \\
\hline 10 & 74 & $\mathrm{~F}$ & $\begin{array}{l}\text { Laparotomy } \\
\text { Extirpation }\end{array}$ & Neurilemoma & 4,5 & 700 & 4000 & 21 & 1 \\
\hline 11 & 37 & $\mathrm{~F}$ & $\begin{array}{l}\text { Extirpation and } \\
\text { anterior rectum } \\
\text { resection }\end{array}$ & $\begin{array}{l}\text { Mucinous } \\
\text { cystadenoma }\end{array}$ & 5 & 800 & 500 & 13 & 5 \\
\hline 12 & 41 & $\mathrm{~F}$ & $\begin{array}{l}\text { Laparotomy } \\
\text { Extirpation }\end{array}$ & Leiomyoma & 1,75 & 853 & 500 & 11 & 0 \\
\hline 13 & 56 & $\mathrm{~F}$ & $\begin{array}{l}\text { Laparotomy } \\
\text { Extirpation }\end{array}$ & Fibroma & 1,3 & 220 & 200 & 10 & 0 \\
\hline 14 & 38 & $\mathrm{~F}$ & $\begin{array}{l}\text { Laparotomy } \\
\text { Extirpation }\end{array}$ & Dermoid cyst & 2,25 & 210 & 50 & 12 & 0 \\
\hline
\end{tabular}

M: male; F: female

\section{Report of a Representative Case (CAse 8)}

39 year old female was admitted to Vilnius university Hospital "Santariskiu klinikos" with diagnosis of acute mechanical obstruction. She complained of severe abdominal pain and constipation for 3 days. Patient reported having abdominal discomfort for 3 years. For last 6 months patient felt tension in lower abdomen and around rectum, as well as difficulty on passing urine.

On clinical examination abdomen was grossly distended, tympanic with active bowel peristaltic sounds. Digital rectal examination revealed a hard, smooth mass at $7 \mathrm{~cm}$ level, compressing rectum from outside. Abdominal x-ray showed appearances suggestive of bowel obstruction. Patient had initial conservative treatment for bowel obstruction (nasogastric tube, infusion therapy, fasting).

Laboratory test results and ultrasound findings were insignificant. MRI revealed homogenous, clearly bordered 118 × 93 x $130 \mathrm{~mm}$ structure, compressing rectum and bladder (Fig. 1 and 2). Based on these findings the diagnosis of retrorectal tumour without apparent signs of malignancy was made.

Total resection of the tumour was performed. The size was $14 \times 7 \times 10 \mathrm{~cm}$, it weighed $680 \mathrm{~g}$ (Fig. 3). Postoperative recovery was uneventful. Histologically the tumour was found to be a lipoma. Patient was asymptomatic after 1,5 year. There were no signs of recurrence on clinical, digital rectal and ultrasound examination. 


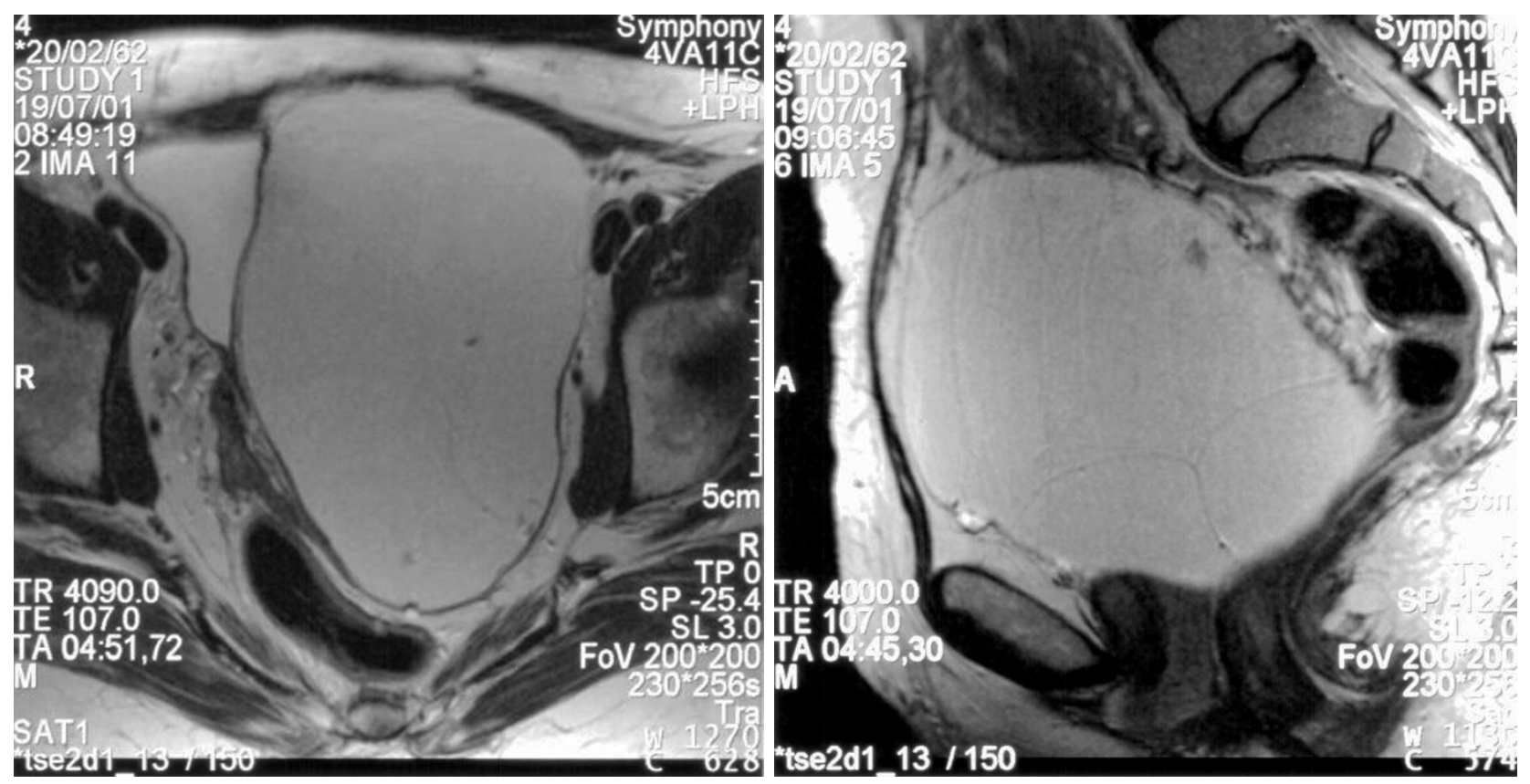

Fig. 1. Axial MRI view of the tumor.

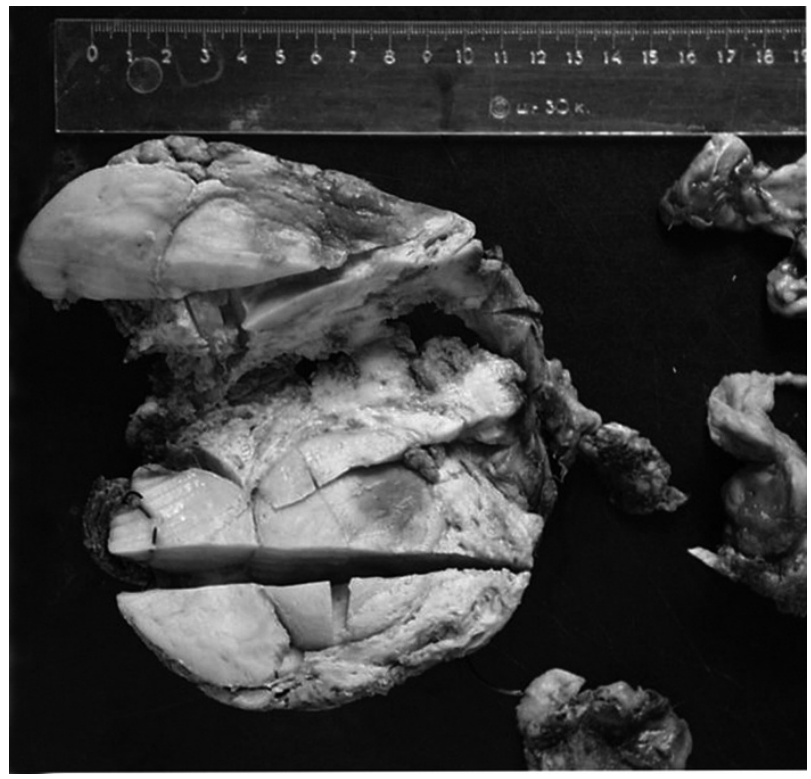

Fig. 2. Sagital MRI view of the tumor.

\section{Discussion}

Because of the rarity of retrorectal tumours the literature is limited to individual case reports, only a few large case series are present. Our study presents significant number of cases in view of scarce information available on this matter.

Clinical examination plays a vital role in diagnosing retrorectal tumours. We had an interesting case, where asymmetric gluteal fold indicated presacral lesion. It was corrected after the operation (Fig. 4).

Plain abdominal $\mathrm{x}$-rays may reveal solid tumours compressing, invading, or displacing the sacrum on the $\mathrm{x}$-ray. The pathognomonic scimitar sign caused by a unilateral sacral defect indicates presence of anterior sacral meningocele [2]. Chronic fistulae can be evaluated with a fistulogram, which documents anato-

4 Fig. 3. Macroscopic view of the tumor.
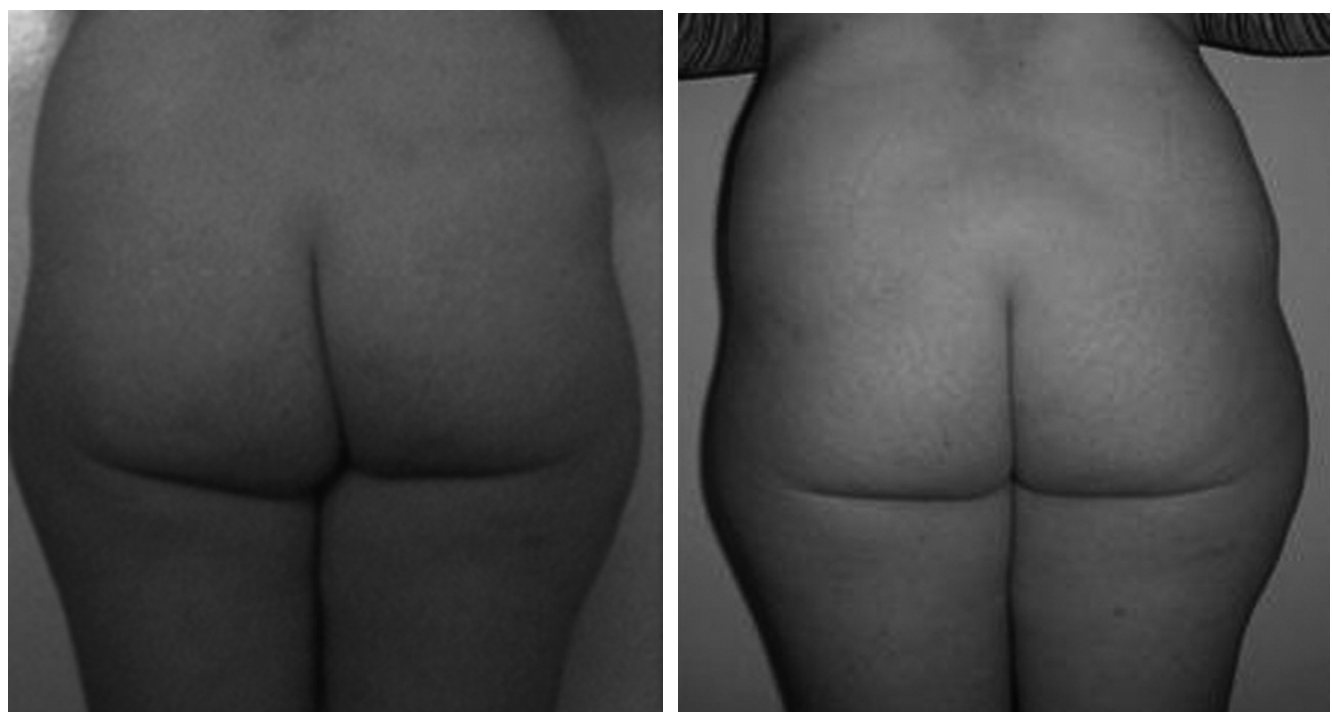

Fig. 4. Gluteal fold before (left) and after (right) the operation. 
my and rules out communication with the rectum [14].

A CT scan of the pelvis can distinguish cystic from solid lesions and assess for sacral involvement or invasion to adjacent structures. MRI shows soft-tissue planes, evaluates the presence or absence of bony invasion and nerve involvement. Preoperative imaging plays a key role in planning the surgical treatment.

Biopsies can cause fatal septic complications and should be performed only when the lesion appears to be unresectable and a tissue diagnosis is required to guide adjuvant therapy $[3,24]$. Tumour seeding may also occur during biopsy - it has been shown that poorly planned biopsies and incomplete debulking operations increase the risk of local recurrence and metastasis [25]. In our study biopsies were performed in other treatment centres before admission to Vilnius University Hospital.

Surgical treatment is based on the size of the tumour, its rostral and caudal extent, involvement of visceral structures and sacrum, features of malignancy on imaging studies. If the tumour is above S3 level, abdominal approach is recommended. Tumours below S3 can be extirpated using perineal approach, as it results in a quicker recovery [26]. For very low lying lesions Buchs et al. [27] recommend intersphincteric posterior approach for preservation of good sphincter function. Visceral or sacral involvement requires abdominal or combined approach irrespective to tumour level. Most of the tumours in our study were above S3 level; therefore laparotomy was used in almost all of the operations. Alternative operative methods include transrectal [28], transvaginal [29] approaches. There are reports of successful use of laparoscopy $[30,31]$ and transanal endoscopic microsurgery [32] for retro rectal lesions.

Postoperative recovery was complicated by wound infection in $14 \%$ of patients in our study. Jao et al. [2] report similar $10 \%$ postoperative infection rate.

Large proportion of patients in our study had undergone surgical interventions before definitive surgical treatment. Singer et al. [14] describe similar diagnostic and treatment difficulties. Retrorectal lesions in female patients can mimic gynaecological pathology. Misdiagnosis could be avoided by performing digital rectal examination when there are unexplained gynaecological symptoms.

Due to proximity of retrorectal space and the genitourinary organs, presacral tumours are often dealt by specialists of other surgical fields. Patients with this rare pathology are to be treated in a major tertiary hospital by surgeons, who are able to operate safely in the retrorectal space.

\section{REFERENCES}

1. Uhlig BE, Johnson RL. Presacral tumors and cysts in adults. Dis Colon Rectum 1975; 18:581-9.

2. Jao SW, Beart RW Jr, Spencer RJ, Reiman HM, IlstrupDM. Retrorectal tumors. Mayo Clinic experience, 1960-1979. Dis Colon Rectum 1985; 28: 644-52.

3. Hobson KG, Ghaemmaghami V, Roe JP, Goodnight JE, Khatri JP. Tumors of the retrorectal space. Dis Colon Rectum 2005; 48: 1964-74.

4. Spencer RJ, Jackman RJ. Surgical management of precoccygeal cysts. Surg Gynecol Obstet 1962; 115:449-52.
5. Garcia-Armengol J, Garcia-Botello S, Martinez-Soriano F et al. Review of the anatomic concepts in relation to the retrorectal space and endopelvic fascia: Waldeyer's fascia and the rectosacral fascia. Colorectal Dis 2008; 10 (3): 298-302

6. Glasgow SC, Birnbaum EH, Lowney JK, et al. Retrorectal tumors: a diagnostic and therapeutic challenge. Dis Colon Rectum 2005; 48:1581-1587

7. Bohm B, Milsom JW, Fazio VW, Lavery IC, Church JM,Oakley JR. Our approach to the management of congenital presacral tumors in adults. Int J Colorectal Dis 1993; 8:134-8.

8. Stewart RJ, Humphreys WG, Parks TG. The presentation and management of presacral tumours. Br J Surg 1986; 73:153-5.

9. Hjermstad BM, Helwig EB. Tailgut cysts. Report of 53 cases. Am J Clin Pathol 1988; 89(2):139-47

10. Cho BC, Kim NK, Lim BJ et al. A carcinoembryonic antigen-secreting adenocarcinoma arising in tailgut cyst: clinical implications of carcinoembryonic antigen. Yonsei Med J, 2005; 46(4):555-61

11. Paramythiotis D, Papavramidis TS, Michalopoulos A, Papadopoulos VN, Apostolidis S, Televantou D, Hytiroglou P. Chronic constipation due to presacral teratoma in a 36year-old woman: a case report. J Med Case Reports. 2010; $4: 23$.

12. Sobrado CW, Mester M, Simonsen OS, Justo CR, deAbreu JN, Habr-Gama A. Retrorectal tumors complicating pregnancy. Report of two cases. Dis Colon Rectum 1996; 39:1176-9.

13. Haribhakti SP, Choudhary CG, Sikora SS. Malignant retrorectal teratoma presenting as an infected perianal sinus. Trop Gastroenterol 1995; 16(2):117-8

14. Singer MA, Cintron JR, Martz JE, et al. Retrorectal cysts: a rare tumor frequently misdiagnosed. J Am Coll Surg 2003; 196:880-886

15. Edwards M. Multilocular retrorectal cystic disease-cysthamartoma: report of twelve cases. Dis Colon Rectum 1961; 4:103-10

16. Cody HS III, Marcove RC, Quan SH. Malignant retrorectal tumors: 28 years' experience at Memorial Sloan-Kettering Cancer Center. Dis Colon Rectum 1981; 24: 501506

17. Fourney DR, Gokaslan ZL. Current management of sacral chordoma. Neurosurg Focus 2003; 15(2): 1-5

18. Anderson FM, Burke BL. Anterior Sacral Meningocele. A presentation of three cases. JAMA. 1977 Jan 3;237(1):3942.

19. Amornfa J, Taecholarn C, Khaoroptham S. Currarino syndrome: report of two cases and review of the literature. J Med Assoc Thai. 2005 Nov;88(11):1697702.

20. Payer M: Neurological manifestation of sacral tumors. Neurosurg Focus 15(2):E1, 2003

21. Witherspoon P, Armitage J, Gatt M et al. Laparoscopic excision of retrorectal schwannoma. Dis Colon Rectum. 2010 Jan; 53(1):101-3.

22. Sciubba DM, Petteys RJ, Garces-Ambrossi GL, Noggle JC, McGirt MJ, Wolinsky JP, Witham TF, Gokaslan ZL. Diagnosis and management of sacral tumors. J Neurosurg Spine. 2009 Mar;10(3):244-56.

23. Glasgow SC, Dietz DW. Retrorectal tumors. Clin Colon Rectal Surg. 2006; 19(2):61-8.

24. Verazin G, Rosen L, Khubchandani IT et al. Retrorectal tumor: is biopsy risky? South Med J. 1986 Nov; 79(11):1437-9.

25. Bergh P, Kindblom LG, Gunterberg B, Remotti F, Ryd W, Meis-Kindblom JM. Prognostic factors in chordoma of the sacrum and mobile spine: a study of 39 patients. Cancer. 2000 May 1;88(9):2122-34. 
26. Abel ME, Nelson R, Prasad ML, Pearl RK, Orsay CP, Abcarian H. Parasacrococcygeal approach for the resection of retrorectal development cysts. Dis Colon Rectum 1985; 28: 855-858.

27. Buchs N, Taylor S, Roche B. The posterior approach for low retrorectal tumors in adults. Int J Colorectal Dis. 2007 Apr;22(4):381-5.

28. Pidala MJ, Eisenstat TE, Rubin RJ, Salvati EP. Presacral cysts: transrectal excision in select patients. Am Surg 1999 65:112-115

29. Aslan E. Transvaginal excision of a retrorectal tumor presenting as rectocele. Erdogan Aslan Int Urogynecol J Pelvic Floor Dysfunct. 2008 Dec; 19(12):1715-7.

30. Gunkova P, Martinek L, Dostalik J, Gunka I, Vavra P, Mazur M. Laparoscopic approach to retrorectal cyst. World J Gastroenterol. 2008 Nov; 14(42):6581-3.

31. Chen Y, Xu H, Li Y, Li J, Wang D, Yuan J, Liang Z. Laparoscopic resection of presacral teratomas J Minim Invasive Gynecol. 2008 Sep-Oct;15(5):649-51.
32. Zoller S, Joos A, Dinter D, Back W, Horisberger K, Post S, Palma P. Retrorectal tumors: Excision by transanal endoscopic microsurgery Rev Esp Enferm Dig. 2007 Sep; 99(9):547-50.

Received: May 12, 2010 / Accepted: July 15, 2010

Address for correspondence:

Kestutis Strupas

Santariskiu g. 2

08661 Vilnius,

Lithuania

Tel.: $\quad+3705236250$

Fax: $\quad+37052365101$

E-mail: Kestutis.Strupas@santa.lt 